\title{
INFLUENCE OF DIETARY PROTEIN ON THE FRACTIONATION OF SELENIUM IN THE RUMEN OF SHEEP
}

\author{
A. B. Serra', S. D. Serra and 'T. Fujihara ${ }^{2}$ \\ Faculty of Life and Environmental Science (formerly Faculty of Agriculture), Shimane University, \\ Matsue-shi, Shimane, 690 Japan
}

\begin{abstract}
Summary
The effects of diets differing in protein content through soybean meal supplementation on ruminal fractionation of selenium (Se) were studied. A $3 \times 3$ Latin square design was used with three Japanese Corriedale wethers $(45 \mathrm{~kg}$ average body weight), three periods, and three dietary treatments. The three dietary treatments were: Diet 1 , without soybean meal supplementation (14\% crude protein, CP); Diet 2, with 10\% soybean meal supplementation (16.5\% CP); and Diet 3, with $20 \%$ soybean meal supplementation $(19 \% \mathrm{CP})$. All the diets had a Se supplementation in the form of sodium selenite at $0.2 \mathrm{mg} \mathrm{Se} / \mathrm{kg}$ dietary DM. The Se supplement and the concentrate mixture were fed only in the morning before the hay was given. Daily feeding schedule for hay was set at 09:00 and 17:00 h. On the final day of the collection period, ruminal fluid samples were obtained at $0.5,2,6,12$ and $24 \mathrm{~h}$ post-feeding starting at 09:00 h. Total ruminal fluid Se was markedly higher $(\mathrm{p}<0.05)$ in Diet 3 than those in Diets 1 and 2 at almost all sampling time except at $24 \mathrm{~h}$. The proportion of Se in soluble protein to the total ruminal Se was higher $(\mathrm{p}<0.05)$ in Diet $3(40 \%)$ followed by Diet $2(28 \%)$ and Diet $1(21 \%)$. The proportion of free inorganic Se to the total ruminal Se was the reverse, especially after two hours where Diet $1(p<0.05)$ was higher than the other diets. Bacterial Se was lower $(p<0.05)$ in Diet 1 than those in Diets 2 and 3 at any sampling time. The highest was observed at $2 \mathrm{~h}$ postprandially in all diets with a value of $42 \mathrm{l}, 556,655 \mu \mathrm{g} / \mathrm{kg}$ bacterial DM for Diet 1,2 and 3, respectively. No differences $(\mathrm{p}>0.05$ ) were observed on ruminal $\mathrm{pH}$, ammonia and total volatile fatty acids although increasing protein supplementation tended to decline the ruminal $\mathrm{pH}$ and increase ruminal ammonia. This study concludes that increasing dietary protein content by soybean meal supplementation can affect the ruminal Se metabolism.
\end{abstract}

(Key Words: Selenium, Selenite, Ruminal Selenium, Bacterial Selenium, Ruminal Ammonia, Volatile Fatty Acid, Sheep)

\section{Introduction}

Selenium (Se) nutrition of ruminants is unique compared to those monogastric animals because the presence of rumen of the former. Thus, the dietary Se of the ruminants is not only for the animal per se but also including those ruminal microbes. Previous reports (Hidiroglou et al., 1968; Paulson et al., 1968; Whanger et al., 1968; Hudman and Glenn, 1984) indicated that ruminal microbes are capable of incorporating Se into

'On-leave from Central Luzon State University, Nueva Ecija, 3120 Philippines.

${ }^{2}$ Address reprint requests to Dr. T. Fujihara, Faculty of Life and Environmental Science, Shimane University, Matsue-shi, 690 Japan.

Received November 17, 1995

Accepted May 7, 1996 their cells. Upon introducing into the rumen compartment, the Se uptake of ruminal microbes is very fast especially in the first three hours postprandially (Serra et al., 1994). These microbes play a key role in the conversion of dietary Se into unavailable forms (Cousins and Cairney, 1961; Peterson and Spedding, 1963; Lopez et al., 1969; Hudman and Glenn, 1984). As well as bacterial Se, Se can be fractionated into free inorganic $\mathrm{Se}$ and $\mathrm{Se}$ in soluble protein in the rumen (Serra et al., 1994).

Due to the influence of the rumen environment, Se requirement could vary depending on the type or kind of diet. Diet affects ruminal functions and therefore nutrient metabolism including Se. In the present study, soybean meal was supplemented to increase the dietary protein and studied its effects on ruminal Se metabolism specifically the fractionation of ruminal Se between bacteria, free 
organic and soluble protein fractions.

\section{Materials and Methods}

The full details of the experimental procedures were discussed in the companion paper (Serra et al., 1996). The salient features are given below:

\section{Experimental animals, diets and design}

The study used a $3 \times 3$ Latin square design with three Japanese Corriedale wethers ( $45 \mathrm{~kg}$ average body weight), three periods ( $7 \mathrm{~d}$ dietary adjustment followed by $5 \mathrm{~d}$ total collection of urine and feces), and three dietary treatments. The three dietary treatments were: Diet 1 , without soybean meal supplementation ( $14 \%$ crude protein, CP); Diet 2, with $10 \%$ soybean meal supplementation $(16.5 \% \mathrm{CP})$; and Diet 3, with $20 \%$ soybean meal supplementation (19\% $\mathrm{CP}$ ). All the diets had a Se supplementation as sodium selenite at $0.2 \mathrm{mg} \mathrm{Se} / \mathrm{kg}$ dietary DM. The Se was mixed to the carrier, $(0.2 \mathrm{~g} \mathrm{Se} / \mathrm{kg}$ wheat flour ). The Se supplement and the concentrate mixture were fed only in the morning before the hay was given. Daily feeding schedule for hay was set at 09:00 and 17:00 h.

\section{Sample collection}

Feed intake was recorded daily. Subsamples of the diet were obtained several times during the experiment and composited for analysis. Subsamples of feces or urine were obtained daily with total weight or volume recorded. The feed and fecal samples were dried at $60^{\circ} \mathrm{C}$ for $48 \mathrm{~h}$ and ground through a $1 \mathrm{~mm}$ screen in a grinding mill and saved for later analysis. Urine samples were acidified with $10 \%$ sulfuric acid (100 $\mathrm{ml} / \mathrm{L}$ urine) and kept in the freezer $\left(-20^{\circ} \mathrm{C}\right)$ before analysis.

On the final day of the collection period, ruminal fluid samples obtained at $0.5,2,6,12$ and $24 \mathrm{~h}$ post-feeding starting at 09:00 h. Time 24 could be considered also as time 0 . Immediately after sampling, $\mathrm{pH}$ was measured using a pH meter (Model M-8L, Horiba, Tokyo, Japan) and later mercuric chloride drops were added as preservative. The fluid sample was strained using four layers of gauze cloth and then frozen at $-20^{\circ} \mathrm{C}$ and later analyzed.

\section{Laboratory analyses}

Diet and fecal samples were analyzed for dry matter (DM), CP and ash following the procedures of AOAC (1984). Urine samples were analyzed for their CP contents. Moreover, the diet, fecal and urine samples were digested with nitric and perchloric acids $(3: 1 \mathrm{v} / \mathrm{v})$ and their Se contents were analyzed following the fluorometric procedure of Watkinson (1966) and the fluorescence spectrophotometer used was Hitachi 204 (Hitachi Ltd., Tokyo, Japan). The conditions of the spectrophotometer were presented earlier (Serra et al., 1994).

The ruminal fluid samples were partitioned into various ruminal $\mathrm{Se}$ fractions following the previous procedure (Serra et al., 1994). The different fractions were wet ashed and their Se contents were determined by the procedures mentioned earlier. The ruminal samples were also analyzed for their ammonia-nitrogen (Oser, 1965) and VFA content (Erwin et al., 1961).

\section{Statistical analyses}

All results are expressed as means $\pm \operatorname{SEM}(n=3)$ unless otherwise stated. Data were analyzed by ANOVA in $3 \times 3$ Latin square (Steel and Torrie, 1980; Statistica for the Macintosh ${ }^{\mathrm{TM}}$ Release 4.1, Statsoft, Inc., Tulsa, $\mathrm{OK})$. The sum of squares was partitioned into the main effect of animal, period and treatment. When the main effect was significant $(p<0.05)$, means were compared using least significance difference. Separate analyses of variance were performed for all Se ruminal fractions and ruminal characteristics at each hour of sampling. Correlation and regression analysis were also done among the measures affecting the bioavailability of Se.

\section{Results}

The Se concentration of ruminal fluid fractions are presented in table 1 . Higher $(\mathrm{p}<0.05)$ total ruminal $\mathrm{Se}$ was found at every sampling time in Diet 3 that those in Diets 2 and 1 except at time 24 or 0 . At time 24 or 0 , the total ruminal Se was at the lowest. Then, it peaked at $2 \mathrm{~h}$ after feeding and declined subsequently. Diet 3 ruminal Se values had increased 37 and $20 \%$ over Diet 1 and Diet 2, respectively.

Free inorganic Se in ruminal fluid was lower $(p<$ 0.05 ) in Diet 3 over Diets 2 and 1 at time 24 or 0 . At $2 \mathrm{~h}$ after feeding, Diet 1 was higher $(p<0.05)$ than the other two diets. No significant differences were noted at other sampling times. It should be noted that at $2 \mathrm{~h}$ postprandially the free inorganic Se was at its peak.

Selenium in soluble protein of ruminal fluid was different $(p<0.05)$ across diets at 24 or $0,0.5$ and $2 \mathrm{~h}$ postprandially. At time 6 and 12, Diet 3 was higher $(p<$ 0.05 ) than those in Diets 2 and 1. The highest value obtained was after two hours regardless of the diets.

Selenium content of ruminal bacteria was presented in figure 1. Diet 1 was lower $(p<0.05)$ in bacterial Se content in every sampling time compared to those Diets 2 and 3. At time 24 or 0 , the value obtained for Diets 1, 2, 
and 3 was 226,326 , and $344 \mu \mathrm{g} / \mathrm{kg}$ bacterial $\mathrm{DM}$, respectively. It increased to $421,556,655 \mu \mathrm{g} / \mathrm{kg}$ bacterial DM at two hours in Diets 1, 2, and 3, respectively. Subsequently, it declined in succeeding time.

TABLE 1. SELENIUM CONCENTRATION OF DIFFERENT RUMINAL FLUID FRACTIONS'

\begin{tabular}{|c|c|c|c|}
\hline Hour & Diet 1 & Diet 2 & Diet 3 \\
\hline & Total ruminal & luid $\mathrm{Se}, \mu \mathrm{g} / \mathrm{k}$ & lluid \\
\hline 0.5 & $6.04 \pm 0.27^{\mathrm{a}}$ & $6.78 \pm 0.18^{a}$ & $8.45 \pm 0.53^{b}$ \\
\hline 2 & $6.63 \pm 0.19^{a}$ & $7.50 \pm 0.92^{\mathrm{a}}$ & $9.13 \pm 0.45^{b}$ \\
\hline 6 & $5.60 \pm 0.67^{\mathrm{a}}$ & $5.92 \pm 0.36^{\mathrm{a}}$ & $8.09 \pm 0.22^{b}$ \\
\hline 12 & $5.17 \pm 0.18^{\mathrm{a}}$ & $5.14 \pm 0.42^{\mathrm{a}}$ & $6.42 \pm 0.22^{\mathrm{b}}$ \\
\hline 24 & $4.67 \pm 1.17$ & $4.50 \pm 0.29$ & $5.30 \pm 0.15$ \\
\hline Mean & $5.62 \pm 0.50$ & $5.97 \pm 0.31$ & $7.48 \pm 0.31$ \\
\hline
\end{tabular}

Free inorganic Se, $\mu \mathrm{g} / \mathrm{kg}$ ruminal fluid ${ }^{3}$

$\begin{array}{clll}0.5 & 2.55 \pm 0.30 & 2.23 \pm 0.12 & 1.45 \pm 0.28 \\ 2 & 3.73 \pm 0.74^{\mathrm{a}} & 2.10 \pm 0.29^{\mathrm{b}} & 1.24 \pm 0.14^{\mathrm{b}} \\ 6 & 2.19 \pm 0.31 & 1.67 \pm 0.28 & 1.10 \pm 0.10 \\ 12 & 1.60 \pm 0.25 & 1.41 \pm 0.28 & 0.95 \pm 0.13 \\ 24 & 1.72 \pm 0.06^{\mathrm{a}} & 1.00 \pm 0.09^{\mathrm{a}} & 0.57 \pm 0.17^{\mathrm{b}} \\ \text { Mean } & 2.36 \pm 0.33 & 1.68 \pm 0.21 & 1.06 \pm 0.19\end{array}$

Se in soluble protein, $\mu / \mathrm{kg}$ ruminal fluid ${ }^{3}$

$\begin{array}{cccc}0.5 & 1.17 \pm 0.27^{\mathrm{a}} & 2.11 \pm 0.17^{\mathrm{b}} & 3.22 \pm 0.09^{\mathrm{c}} \\ 2 & 1.57 \pm 0.19^{\mathrm{a}} & 2.20 \pm 0.12^{\mathrm{b}} & 3.72 \pm 0.15^{\mathrm{c}} \\ 6 & 1.45 \pm 0.21^{\mathrm{a}} & 1.80 \pm 0.12^{\mathrm{a}} & 3.55 \pm 0.12^{\mathrm{b}} \\ 12 & 1.21 \pm 0.15^{\mathrm{a}} & 1.32 \pm 0.04^{\mathrm{a}} & 2.74 \pm 0.14^{\mathrm{b}} \\ 24 & 0.59 \pm 0.18^{\mathrm{a}} & 1.12 \pm 0.06^{\mathrm{b}} & 1.76 \pm 0.08^{\mathrm{c}} \\ \text { Mean } & 1.20 \pm 0.20 & 1.71 \pm 0.10 & 3.00 \pm 0.11\end{array}$

'Values are means \pm SEM, $n=3$ sheep/treatment. Figures within row with different superscript differ $(p<0.05)$.

${ }^{2}$ Analyzed from the supernatant of ruminal fluid after low centrifugation $(2,000 \times \mathrm{g})$; also contains ruminal microbes.

${ }^{3}$ Analyzed from the supernatant of ruminal fluid after high centrifugation $(24,000 \times \mathrm{g})$ and then partitioned into free inorganic $\mathrm{Se}$ and $\mathrm{Se}$ in soluble protein by the addition of $5 \%$ trichloracetic acid and centrifuged to $3,000 \times \mathrm{g}$.

Ruminal $\mathrm{pH}$, ammonia and volatile fatty acids characteristics are presented in table 2 . No differences $(p$ $>0.05$ ) on various measures of ruminal characteristics were observed although increasing protein supplementation tended to decline the ruminal $\mathrm{pH}$ and to increase ruminal ammonia.
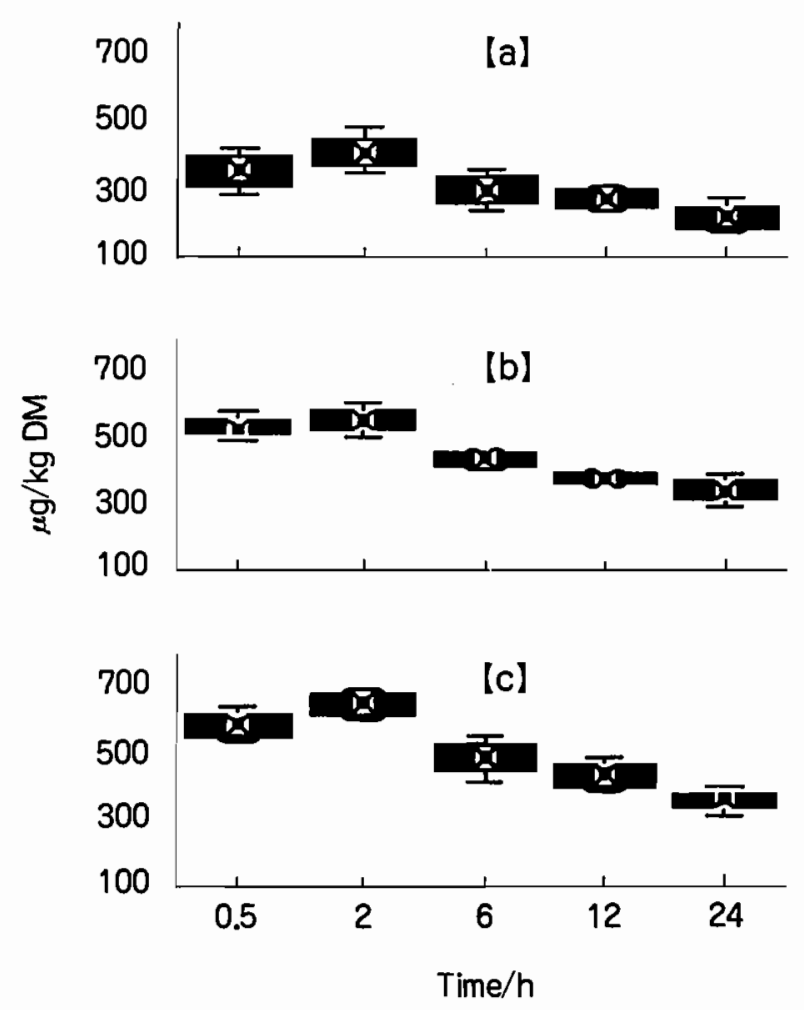

Figure 1. Concentrations of Se in ruminal bacteria as influenced by dietary protein content: $a$, Diet 1: b, Diet 2; c, Diet 3. Diet 1 was lower $(p<0.05)$ in bacterial Se content in every sampling time compared to those Diets 2 and 3. Box and whisker plots are Mean, SE and SD.

\section{Discussion}

The ruminal environment is being thought as the reason for the low bioavailabilities of Se and other trace elements in ruminants. Selenium present in the rumen is of both dietary and an endogenous origin. Whatever its origin, Se like many trace elements in the rumen forms complexes with anionic ligands which may be either inorganic or organic (Durand and Kawashima, 1980) or reduced into elemental Se (Cousins and Caimey, 1961; Peterson and Spedding, 1963; Lopez et al., 1969; Durand and Kawashima, 1980; Hudman and Glenn, 1984). The forms of Se in the rumen depend on type, kind of diet or feeding management (Gerloff, 1992).

The increase in dietary protein as a result of soybean meal supplementation markedly increased the concentration of Se in ruminal fluid (table 1). A previous study (Serra et al., 1994) indicated that only 10 and 15\% of the Se content of the ruminal fluid was associated with 
TABLE 2. INFLUENCE OF PROTEIN SUPPLEMENTATION ON SOME RUMINAL CHARACTERISTICS'

\begin{tabular}{|c|c|c|c|}
\hline Hour & Diet 1 & Diet 2 & Diet 3 \\
\hline & \multicolumn{3}{|c|}{ 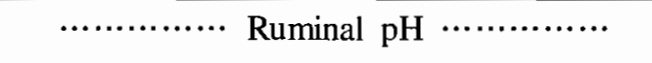 } \\
\hline 0.5 & $6.93 \pm 0.81$ & $6.86 \pm 0.05$ & $6.80 \pm 0.12$ \\
\hline 2 & $6.89 \pm 0.01$ & $6.78 \pm 0.18$ & $6.55 \pm 0.01$ \\
\hline 6 & $6.80 \pm 0.10$ & $6.72 \pm 0.19$ & $6.45 \pm 0.05$ \\
\hline 12 & $6.40 \pm 0.10$ & $6.27 \pm 0.22$ & $6.01 \pm 0.13$ \\
\hline 24 & $6.93 \pm 0.15$ & $6.83 \pm 0.04$ & $6.67 \pm 0.10$ \\
\hline \multirow[t]{2}{*}{ Mean } & $6.79 \pm 0.11$ & $6.69 \pm 0.14$ & $6.50 \pm 0.08$ \\
\hline & \multicolumn{3}{|c|}{ …. Ruminal ammonia $(\mathrm{mg} / 100 \mathrm{ml}) \quad \cdots \cdots$} \\
\hline 0.5 & $21.80 \pm 4.73$ & $22.37 \pm 5.31$ & $27.99 \pm 3.84$ \\
\hline 2 & $28.96 \pm 0.03$ & $29.85 \pm 3.71$ & $29.25 \pm 2.54$ \\
\hline 6 & $15.37 \pm 0.60$ & $15.64 \pm 1.87$ & $17.22 \pm 0.97$ \\
\hline 12 & $16.60 \pm 1.17$ & $16.78 \pm 3.43$ & $20.13 \pm 3.43$ \\
\hline 24 & $16.11 \pm 2.84$ & $16.59 \pm 3.62$ & $16.49 \pm 0.86$ \\
\hline \multirow[t]{2}{*}{ Mean } & $19.77 \pm 1.87$ & $20.25 \pm 3.59$ & $22.22 \pm 2.33$ \\
\hline & \multicolumn{3}{|c|}{ … Ruminal total VFA, $\mathrm{mmol} / 100 \mathrm{ml} \cdots$} \\
\hline 0.5 & $6.26 \pm 0.57$ & $5.99 \pm 0.62$ & $6.87 \pm 0.71$ \\
\hline 2 & $5.88 \pm 0.02$ & $5.63 \pm 0.58$ & $5.89 \pm 0.38$ \\
\hline 6 & $6.21 \pm 0.05$ & $6.07 \pm 0.97$ & $6.31 \pm 0.66$ \\
\hline 12 & $7.56 \pm 0.70$ & $6.78 \pm 1.10$ & $7.25 \pm 1.07$ \\
\hline 24 & $6.01 \pm 0.58$ & $5.91 \pm 1.04$ & $6.55 \pm 1.05$ \\
\hline \multirow[t]{2}{*}{ Mean } & $6.38 \pm 0.38$ & $6.08 \pm 0.86$ & $6.57 \pm 0.77$ \\
\hline & \multicolumn{3}{|c|}{$\cdots \cdots \cdots$ Acetate $:$ Propionate ratio $\cdots \cdots \cdots$} \\
\hline 0.5 & $5.42 \pm 0.32$ & $4.50 \pm 0.37$ & $4.10 \pm 0.14$ \\
\hline 2 & $4.51 \pm 0.005$ & $4.34 \pm 0.37$ & $3.61 \pm 0.33$ \\
\hline 6 & $4.21 \pm 0.12$ & $4.52 \pm 0.15$ & $4.06 \pm 0.43$ \\
\hline 12 & $4.89 \pm 0.93$ & $3.84 \pm 0.21$ & $3.36 \pm 0.50$ \\
\hline 24 & $5.15 \pm 0.52$ & $5.14 \pm 0.68$ & $4.25 \pm 0.05$ \\
\hline Mean & $4.84 \pm 0.38$ & $4.47 \pm 0.36$ & $3.88 \pm 0.29$ \\
\hline
\end{tabular}

${ }^{1}$ Values are means $\pm \mathrm{SEM}, \mathrm{n}=3$ sheep/treatment. Figures within row are not statistically different $(p>0.05)$.

soluble protein as influenced by selenate and selenite supplementation, respectively, on a diet without protein supplementation (hay alone). When the diets had protein supplementation as in the case of the present study, the proportion of $\mathrm{Se}$ in soluble protein increased to 21,28 and $40 \%$ for Diets 1, 2 and 3, respectively. Thus, there was a great tendency that $\mathrm{Se}$ could be incorporated into protein. Previous paper (Favier, 1989) discussed the synthesis of selenoamino acids from inorganic Se. To accomplish this, sulfur containing amino acids must be present. According to Burk (1991) and Gerloff (1992), inorganic Se was incorporated into the selenoproteins by Se substitution for a sulfur atom in the cysteine residue of the protein. The work of Hudman and Glenn (1984) showed the incorporation of ${ }^{75}[\mathrm{Se}]$-selenite into selenocystine, selenoethionine, selenohomocysteine and selenomethionine.

Free inorganic Se of the ruminal fluid showed a decrease in Se concentration as dietary protein increases (table 1). Thus, more available Se for the host animal was observed in diets with low protein content. In the present study, selenite is the form of Se that was supplemented. Selenite is an oxidized form of Se and the biologically active. If the ruminal environment has a higher reducing capacity due to concentrate supplementation, then more of this oxidized Se may be converted into reduced, unavailable state. This is supported by earlier studies (Harrison and Conrad, 1984; Serra et al., 1994; Serra et al., 1996) which showed that Se absorption and retention are affected by concentrate supplementation.

The higher concentrations of bacterial $\mathrm{Se}$ is another reason for higher Se concentrations of the ruminal fluid brought about by protein supplementation. Diet 2 (16.5\% $\mathrm{CP})$ and Diet $3(19 \% \mathrm{CP})$ had higher $(\mathrm{p}<0.05$, figure 1$)$ concentrations of bacterial Se than that of Diet I $(14 \%$ $\mathrm{CP}$ ). The present study found that even at $0.5 \mathrm{~h}$ after the introduction of Se in the rumen, bacterial Se fraction increased and peaked at $2 \mathrm{~h}$ postprandially. The highest concentration of bacterial Se seen at $2 \mathrm{~h}$ postprandially was 362,556 and $655 \mu \mathrm{g} / \mathrm{kg}$ bacterial DM in Diets 1,2 and 3 , respectively. On hay alone, the highest concentration of bacterial Se obtained was 239 and 249 $\mu \mathrm{g} / \mathrm{kg}$ bacterial DM in selenate and selenite supplemented diets upon $\mathrm{Se}$ introduction in the rumen up to $\mathrm{l} \mathrm{h}$ postprandially (Serra et al., 1994). Many reports indicated the capability of ruminal bacteria in metabolizing inorganic Se (Cousins and Cairney, 1961; Peterson and Spedding, 1963; Hidiroglou et al., 1968; Paulson et al., 1968; Whanger et al., 1968; Hudman and Glenn, 1984) and ability to actively transport selenite (Hudman and Glenn, 1984). The Se incorporated into bacterial cells and its influence on its Se availability to the host animal is not known (Church et al., 1971; Durand and Kawashima, 1980). However, ruminal microorganisms are considered to be the probable cause of the lower absorption of Se in ruminants than in nonruminants (NRC, 1983).

Ruminal environments are affected by type of diets (de Faria and Huber, 1984) as in the case of the present study. Ruminal $\mathrm{pH}$ showed diurnal changes, with lowest value at 
$12 \mathrm{~h}$ after morning feed and the mean $\mathrm{pH}$ of animals fed with the Diet 1 (basal diet; 6.79) was slightly higher than those supplemented with soybean meal (Diet 2, 6.69; Diet $3,6.50$ ). Ruminal ammonia increased with the inclusion of soybean meal in the diet and the trend was Diet $3>$ Diet $2>$ Diet 1 . The distinct peaks of ruminal ammonia values were observed at $2 \mathrm{~h}$ across diets and they all exceeded $23 \mathrm{mg} / 100 \mathrm{ml}$ (suggested value for maximum ruminal fermentation activity according to Mehrez et al., 1977) including the value at $0.5 \mathrm{~h}$ of Diet 3 . The range of ruminal ammonia obtained in this study was 15.37-29.85 $\mathrm{mg} / 100 \mathrm{ml}$. Bondi (1981) stated that $2-50 \mathrm{mg} / 100 \mathrm{ml}$ was the normal range of ruminal ammonia concentrations depending on the diet and time after feeding. Moreover, he cited that the maximal concentration of ammonia could reached about $2 \mathrm{~h}$ after ingestion of the food containimg protein as also observed in the present study.

\section{Conclusion}

These data indicate that increasing dietary protein content by soybean meal supplementation can affect the ruminal environment including the various fractions of ruminal Se. Increasing the dietary protein content tend to increase the concentration of bacterial $\mathrm{Se}$ and $\mathrm{Se}$ in soluble protein but tend to decrease free inorganic Se.

\section{Acknowledgements}

The authors wish to express their appreciation to Ms. M. Horiguchi and Mr. K. Shinchi for their assistance in animal care and laboratory analyses.

\section{Literature Cited}

AOAC. 1984. Official Methods Analysis (14th Ed.). Association of Official Analytical Chemists, Arlington, VA.

Bondi, A. 1981. Metabolism of protein in ruminant animals: A review. Nutr. Rep. Int. 23:993-1004.

Burk, R. F. 1991. Molecular biology of selenium with implication for its metabolism. FASEB. J. 5:2274.

Church, D. C., S. L. Hansard, J. K. Miller and P. D. Whanger. 1971. The trace elements. In: D.C. Church (Ed.) Digestive Physiology and Nutrition of Ruminants. O \& B Books, Inc., Corvallis, OR, pp. 100-156.

Cousins, F. B. and I. M. Cairney. 1961. Some aspects of selenium metabolism in sheep. Aus. J. Agric. Res. 12:927-943.

de Faria, V. P. and J. T. Huber. 1984. Effect of dietary protein and energy levels on rumen fermentation in Holstein steers. J. Anim. Sci. 58:452-459.

Durand, M. and R. Kawashima. 1980. Influence of minerals in rumen microbial digestion. In: Y. Ruckebusch and P. Thivend (Ed.) Digestive Physiology and Metabolism in Ruminants. MTP Press Ltd., Lancaster, England. pp. 375-408.

Erwin, E. S., G. J. Marco and E. M. Emery. 1961. Volatile fatty acids analyses of blood and rumen fluid by gas chromatography. J. Dairy Sci. 44:1769-1774.

Favier, A. 1989. Selenite metabolism. In: J. Neve and A. Favier (Ed.) Selenium in Medicine and Biology. Walter de Guyter, Berlin. pp. 29-50.

Gerloff, B. J. 1992. Effect of selenium supplementation on dairy cattle. J. Anim. Sci. 70:3934-3940.

Harrison, J. H. and H. R. Conrad. 1984. Effect of selenium intake on selenium utilization by the nonlactating dairy cow. J. Dairy Sci. 67:219-223.

Hidiroglou, M., D. P. Heaney and K. J. Jenkins. 1968. Metabolism of inorganic selenium in rumen bacteria. Can. J. Physiol. Pharmacol. 46:229-232.

Hudman, J. F. and A. R. Glenn. 1984. Selenite uptake and incorporation by Selenomonas ruminantium Arch. Microbiol. 140:252-256.

Lopez, P. L., R. L. Preston and W. H. Pfander. 1969. Whole-body retention, tissue distribution and excretion of selenium-75 after oral and intravenous administration in lambs fed varying selenium intakes. J. Nutr. 97:123-132.

Mehrez, A. Z., E. R. Ørskov and I. McDonald. 1977. Rates of rumen fermentation in relation to rumen ammonia concentration. Br. J. Nutr. 38:437-443.

NRC. 1983. Selenium in Nutrition. Revised Ed. National Academy of Sciences-National Research Council. Washington, D.C.

Oser, B. L. 1965. Hawke's Physiological Chemistry (14th Ed.). McGraw-Hill Book Company, New York. p. 1219.

Paulson, G. D., C. A. Baumann and A. L. Pope. 1968. Metabolism of ${ }^{75} \mathrm{Se}$-selenite, ${ }^{75} \mathrm{Se}$-selenite, ${ }^{75} \mathrm{Se}-$ selenomethionine and ${ }^{35} \mathrm{~S}$-sulfate by rumen microorganisms in vitro. J. Anim. Sci. 27:497-504.

Peterson, P. J. and D. J. Spedding. 1963. The excretion by sheep on ${ }^{75}$ Selenium incorporated into red clover (Trifolium pratense L.): the chemical nature of the excreted selenium and its uptake by three plant species. N. Z. J. Agric. Res. 6:13-23.

Serra, A. B., K. Nakamura, T. Matsui, T. Harumoto and T. Fujihara. 1994. Inorganic selenium for sheep. I. Selenium balance and selenium levels in the different ruminal fluid fractions. Asian-Australasian J. Anim. 
Sci. 7:83-89.

Serra, A. B., S. D. Serra and T. Fuj ihara. 1996. Influence of dietary protein on the apparent absoption and retention of selenium in sheep. Asian-Australasian $\mathrm{J}$. Anim. Sci. 9(5): 9(5):551-556.

Steel, R. G. D. and J. H. Torrie. 1980. Principles and Procedures of Statistics: A Biometrical Approach (2nd
Ed.). MacGraw-Hill Book Co., New York.

Watkinson, J. H. 1966. Fluorometric determination of selenium in biological material with 2,3 diaminonaphthalene. Anal. Chem. 38:92-97.

Whanger, P. D., P. H. Weswig and O. H. Muth. 1968. Metabolism of ${ }^{75} \mathrm{Se}$-selenite and ${ }^{75} \mathrm{Se}$-selenomethionine by rumen microorganisms. Fed. Proc. 27:418 (Abstr.). 